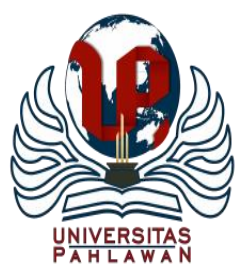

Jurnal Abdidas Volume 1 Nomor 2 Tahun 2020 Halaman 64 - 69

JURNAL ABDIDAS

$\underline{\text { http://abdidas.org/index.php/abdidas }}$

\title{
PENGARUH TERAPI JALAN KAKI 10 MENIT TERHADAP TEKANAN DARAH PADA PRIMIGRAVIDA
}

\author{
Ruri Yuni Astari ${ }^{1}$, Ade Rita Nurlaela ${ }^{2}$ \\ Prodi Kebidanan STIKes YPIB Majalengka ${ }^{1}$ \\ Prodi Keperawatan STIKes YPIB Majalengka ${ }^{2}$ \\ E-mail : ruri ya@yahoo.co.id ${ }^{1}$, aderita@ gmail.com ${ }^{2}$
}

\begin{abstract}
Abstrak
Angka Kematian Ibu (AKI) di Indonesia masih tinggi, hal ini disebabkan karena masih banyaknya ibu hamil dengan risiko tinggi yang salah satunya hipertensi dalam kehamilan (hipertensi gestasional). Hipertensi dalam kehamilan adalah hipertensi yang terjadi pada bulan terakhir kehamilan dengan tekanan darah mencapai 140/90 $\mathrm{mmHg}$ atau lebih. Tujuan pengabdian masyarakat ini untuk mengetahui pengaruh terapi jalan kaki 10 menit terhadap tekanan darah pada ibu primigravida. Metode yang dilakukan simulasi dan pendampingan terapi jalan kaki 3 kali dalam satu minggu. Hasil pengabdian masyarakat menunjukkan bahwa rata-rata tekanan darah pada ibu primigravida sebelum terapi jalan kaki 10 menit sebesar 122,6 mmHg dan sesudah terapi jalan kaki 10 menit sebesar 112,6 mmHg sehingga terjadi penurunan sebesar $10 \mathrm{mmHg}$ dibanding sebelum terapi. Artinya terdapat pengaruh terapi jalan kaki 10 menit terhadap tekanan darah pada ibu primigravida. Terapi jalan kaki 10 menit dapat digunakan sebagai salah satu alternatif asuhan pada ibu hamil dengan hipertensi dan dianjurkan untuk menjaga pola hidup sehat.
\end{abstract}

Kata kunci : terapi jalan kaki, tekanan darah, primigravida

\begin{abstract}
The Maternal Mortality Rate in Indonesia is high, because there are still many pregnant women with high risk that one of the hypertension in pregnancy (gestasional hypertension). Hypertension in pregnancy is the hypertension that occurs in the last month of pregnancy with blood pressure reaching $140 / 90 \mathrm{mmHg}$ or higher than that. The purpose of our community service is to determine the effect of the 10 minute walking therapy on blood pressure in primigravida mothers. The method used are a simulation and the assistance of the 10 minute walking therapy for 3 times in one week. The result of this community service shows that the blood pressure average of primigravida mothers before therapy is 122,6 $\mathrm{mmHg}$. Meanwhile, the average of blood pressure after therapy is $112,6 \mathrm{mmHg}$. So that there is a decrease for $10 \mathrm{mmHg}$ of blood pressure average compared to before therapy. This means that there is an effect of the 10 minute walking therapy on the blood pressure of primigravida mothers. 10 minute walking therapy can be used as an alternative care for pregnant women with hypertension and it is recommended to maintain a healthy lifestyle.
\end{abstract}

Keywords: walking therapy, blood pressure, primigravida

Copyright (c) 2020 Ruri Yuni Astari, Ade Rita Nurlaela

$\triangle$ Corresponding author :

Address : STIKes YPIB Majalengka

Email : ruri ya@yahoo.co.id

ISSN 2721-9224 (Media Cetak)

Phone : 081324389585

ISSN 2721-9216 (Media Online)

DOI: https://doi.org/10.31004/abdidas.v1i2.15 


\section{PENDAHULUAN}

Hipertensi Dalam Kehamilan (HDK) adalah hipertensi yang terjadi saat kehamilan dan biasanya berlangsung setelah 20 minggu usia kehamilan atau bulan terakhir kehamilan dan lebih pada wanita yang sebelumnya normotensif dengan kenaikan tekanan sistolik $30 \mathrm{mmHg}$ dan tekanan diastolik $15 \mathrm{mmHg}$ di atas nilai normal (IBG Manuaba, 2015). HDK menjadi masalah yang serius karena menjadi salah satu penyebab kematian tersering selain perdarahan dan infeksi serta banyak memberikan kontribusi pada morbiditas dan mortalitas ibu hamil (Cunningham F, Leveno K, Bloom S, 2010). Proporsi penyebab utama kematian ibu karena hipertensi pada masa kehamilan di Indonesia sejak tahun 2014 sampai tahun 2017 selalu meningkat berbeda dengan penyebab kematian lainnya yaitu perdarahan dan infeksi yang cenderung menurun. Pada tahun 2014, hipertensi dalam kehamilan berkontribusi sebesar 21,5\%, tahun 2015 sebesar 24,7\%, tahun 2016 sebesar 26,9\% dan tahun 2017 naik menjadi 27,1\% (Kemenkes RI, 2018).

Angka Kematian Ibu (AKI) di Indonesia tahun 2015 sebesar 305 per 100.000 kelahiran hidup. Masih banyak terjadinya kematian ibu dikarenakan masih banyaknya ibu hamil dengan risiko tinggi yang mengalami hipertensi dalam kehamilan (hipertensi gestasional) (Kemenkes RI, 2018). Jumlah kematian ibu di Propinsi Jawa Barat pada tahun 2017 diketahui sebanyak 804 kematian dengan AKI sebesar 86,3 per 100.000 kelahiran hidup. Penyebab kematian ibu yaitu perdarahan sebesar $25 \%$, infeksi sebesar $15 \%$, hipertensi dalam kehamilan sebesar $13 \%$, aborsi sebesar
$13 \%$, sepsis sebesar $10 \%$, serta partus lama sebesar 8\% (Dinas Kesehatan Propinsi Jawa Barat, 2018).

Jumlah kematian ibu di Kabupaten Majalengka tercatat sebanyak 17 orang, penyebabnya yaitu karena HDK sebanyak 9 orang $(52,94 \%)$, perdarahan sebanyak 6 orang $(35,2 \%)$, penyakit jantung sebanyak 1 orang $(5,8 \%)$ dan post sesar sebanyak 1 orang $(5,8 \%)$. Adapun jumlah ibu hamil di Kabupaten Majalengka pada tahun 2018 sebanyak 20.974 orang dan angka kejadian hipertensi dalam kehamilan sebanyak 1.579 orang $(7,5 \%)$. Puskesmas dengan angka kejadian hipertensi dalam kehamilan paling tinggi terdapat di UPTD Puskesmas Argapura yaitu sebanyak 128 orang $(20,8 \%)$ dari jumlah ibu hamil sebanyak 614 orang (Dinas Kesehatan Kabupaten Majalengka, 2019).

Hipertensi pada kehamilan merupakan kejadian yang ditandai dengan tekanan darah di atas nilai normal yaitu tekanan darah di atas 140/90 mmHg. Pengukuran tekanan darah dilakukan secara dua kali setelah pasien beristirahat beberapa menit dengan menggunakan fase $V$ Korotkoff untuk menentukan tekanan diastolik. Gold standart untuk memeriksa tekanan darah adalah memakai sphymomanometer. Edema tidak lagi digunakan sebagai kriteria diagnostik karena kelainan ini terjadi pada banyak wanita hamil normal sehingga tidak lagi dapat digunakan sebagai faktor pembeda (Sabar Surbakti, 2014).

Klasifikasi hipertensi pada kehamilan oleh Working Group of the NHBPEP (2000) dibagi menjadi 4 tipe: 1) hipertensi gestasional 2) preeklampsia dan eklampsia, 3) hipertensi kronis dan 4) preeklampsia superimposed pada hipertensi 
kronis (Cunningham F, Leveno K, 2003). Sekitar 85\% HDK terjadi pada kehamilan pertama atau primigravida dan jika ditinjau dari HDK graviditas yang paling aman adalah kehamilan kedua dan ketiga. Graviditas merupakan faktor yang berkaitan dengan timbulnya hipertensi dalam kehamilan. Frekuensi kejadian hipertensi sebagai penyulit kehamilan lebih tinggi pada primigravida daripada multigravida. Hal tersebut dikarenakan adanya pembentukan blocking antibodies terhadap antigen tak sempurna dan Human Leucocyte Protein $G$ (HLA-G) yang berperan penting dalam modulasi respon imun, sehingga ibu menolak hasil konsepsi (plasenta) atau terjadi intoleransi ibu terhadap plasenta dan terjadi hipertensi selama kehamilan (Lauralee Sherwood, 2010).

Beberapa faktor risiko penyebab hipertensi dalam kehamilan yaitu hamil di usia tua (di atas 35 tahun), pengentalan darah saat hamil, berlebihan dalam mengonsumsi kafein, kurang olahraga, mengonsumsi garam berlebihan, merokok, kebiasaan mengonsumsi minuman alkohol, stres berlebihan, kurangnya asupan nutrisi, memiliki riwayat hipertensi kronis, mengidap gangguan ginjal dan faktor genetik dan obesitas (kegemukan). Untuk mengatasi permasalahan HDK, maka terapi jalan kaki menjadi salah satu penatalaksanaan non farmakologis pada ibu hamil agar pembuluh darah melebar dan tekanan darah menjadi turun (Kusmana, 2016).

Olahraga yang paling dianjurkan untuk ibu hamil adalah jalan-jalan pagi hari, karena di waktu ini ibu hamil mendapatkan udara yang segar dan oksigen yang bagus untuk pernafasan. Jalan kaki adalah suatu kegiatan fisik yang menggunakan otot-otot terutama otot kaki untuk berpindah dari suatu tempat atau ketempat lain (Yuliarti, 2015). Manfaat terapi jalan kaki adalah membuat otot-otot jantung lebih kuat, menormalkan tekanan darah menguatkan otot dasar panggul, dapat mempercepat turunnya kepala bayi kedalam posisi optimal atau normal dan mempersiapkan mental menghadapi persalinan (Kusmiyati, 2014). Olahraga jalan kaki pada ibu hamil memiliki rentang waktu antara 10 sampai 15 menit dengan istirahat dua sampai tiga menit kemudian dilanjutkan kembali 10 sampai 15 menit. Secara umum ibu hamil dianjurkan untuk berolahraga jalan kaki selama 10-15 menit dengan frekuensi tiga kali seminggu dan dicatat denyut laju jantung. Terapi ini sangat dianjurkan terutama pada ibu hamil yang tidak pernah melakukan olahraga karena dapat mempengaruhi penurunan tekanan darah (Mukhamad Taufik, Nur Chakim, 2014).

\section{METODE}

Metode yang digunakan dalam pengabdian masyarakat ini ceramah dan diskusi, simulasi dan kegiatan jalan kaki serta pendampingan terapi jalan kali seminggu tiga kali yaitu hari Senin, Rabu dan Jumat pada ibu primigravida sebanyak 15 orang di Puskesmas Argapura, Kecamatan Argapura, Kabupaten Majalengka.

Tahap pertama dilakukan penjelasan tentang maksud dan tujuan pengabdian, brainstorming terkait kasus HDK bagi ibu hamil yang akan dilakukan terapi jalan kaki, pentingnya terapi jalan kaki bagi ibu hamil untuk menurunkan tekanan darah, teknis kegiatan dan pendampingan oleh 
penulis dan kader Desa Argapura satu orang sampai kegiatan berakhir.

Teknis kegiatan: 1) ibu hamil mengisi inform concent, 2) sebelum terapi jalan kaki ibu di tensi dahulu kemudian baru melakukan jalan kaki selama 10 menit didampingi dan diobservasi menggunakan stopwatch, 3) setelah 3 kali terapi jalan kaki di lakukan, ibu hamil ditensi kembali dan hasil dicatat.

\section{HASIL DAN PEMBAHASAN}

Kegiatan pengabdian dilakukan bulan Juni 2019 dengan mencatat tekanan darah awal (sebelum perlakuan) dan setelah diberi perlakuan yaitu terapi jalan kaki 10 menit selama 3x dalam seminggu kemudian dilakukan pengukuran dan pencatatan tekanan darah kembali (setelah perlakuan).

Tabel 1. Tekanan Darah Sebelum dan Sesudah Terapi Jalan Kaki 10 Menit

\begin{tabular}{|cccccc|}
\hline $\begin{array}{c}\text { TD pada } \\
\text { Primigravi } \\
\text { da }\end{array}$ & Mean & Med & SD & $\begin{array}{c}\text { Mi } \\
\text { - }\end{array}$ & $\begin{array}{c}\text { 95\% } \\
\text { CI } \\
\text { Ma }\end{array}$ \\
\hline Sebelum & 122.6 & 120 & 8. & 110 & 117.7 \\
Terapi & & & 83 & - & - \\
Jalan Kaki & & & 7 & 140 & 127.5 \\
10 Menit & & & & & \\
Sesudah & 112.6 & 110 & 8. & 100 & 107.7 \\
Terapi & & & 83 & - & - \\
$\begin{array}{c}\text { Jalan Kaki } \\
\text { 10 Menit }\end{array}$ & & & 7 & 130 & 117.5 \\
\hline
\end{tabular}

Berdasarkan tabel 1, menunjukkan bahwa tekanan darah pada ibu hamil primigravida sebelum terapi jalan kaki 10 menit diperoleh ratarata sebesar 122,6 dan tekanan darah paling rendah adalah 110 dan paling tinggi adalah 140.
Sedangkan sesudah terapi jalan kaki 10 menit diperoleh rata-rata sebesar 112,6 dan tekanan darah paling rendah adalah 100 dan paling tinggi adalah 130.

Tabel 2. Pengaruh Terapi Jalan Kaki 10 Menit

Terhadap Tekanan Darah pada Primigravida

\begin{tabular}{|cccccc|}
\hline $\begin{array}{c}\text { TD pada } \\
\text { Primigravid } \\
\text { a }\end{array}$ & Mean & n & SD & t & $\begin{array}{c}\boldsymbol{\rho} \\
\text { valu } \\
\mathbf{e}\end{array}$ \\
\hline $\begin{array}{c}\text { Sebelum } \\
\text { Terapi Jalan } \\
\text { Kaki 10 } \\
\text { Menit }\end{array}$ & 122.6 & 15 & 8.837 & 5,916 & 0,00 \\
$\begin{array}{c}\text { Sesudah } \\
\text { Terapi Jalan } \\
\text { Kaki 10 } \\
\text { Menit }\end{array}$ & 112.6 & 15 & 8.837 & & \\
\hline
\end{tabular}

Hasil pengabdian masyarakat didapatkan data bahwa rata-rata tekanan darah ibu sebelum terapi jalan kaki 10 menit yaitu 122,6 sedangkan sesudah terapi jalan kaki 10 menit yaitu 112,6. Hasil rata rata menunjukkan terjadi penurunan sebesar 10 poin. Artinya adanya pengaruh terapi jalan kaki terhadap penurunan tekanan darah sebesar $10 \mathrm{mmHg}$. Terapi jalan kaki dapat dijadikan alternatif sebagai terapi non farmakologis untuk menurunkan tekanan darah pada ibu hamil dikarenakan jalan kaki akan memperbaiki peredaran darah sehingga tekanan darah pada ibu yang melakukan terapi ini akan mengalami penurunan. Latihan jalan kaki dapat memperlancar peredaran darah untuk mengambil, mengedarkan dan menggunakan oksigen serta menaikkan elastisitas pembuluh-pembuluh darah dan jantung sehingga akan bekerja secara normal. Peningkatan efisiensi kerja jantung dicerminkan dengan penurunan tekanan darah sistolik, 
sedangkan tahanan perifer dicerminkan dengan penurunan tekanan diastolik (Lauralee Sherwood, 2010). Mekanisme terjadinya penurunan tekanan darah karena pembuluh darah mengalami pelebaran dan relaksasi sehingga aktivitas memompa jantung menjadi berkurang (Olea MA, 2017). Pada individu yang rutin berolahraga jantungnya berkontraksi lebih sedikit untuk memompakan darah dengan volume yang sama dibandingkan dengan individu yang jarang berolah raga.

Jalan kaki akan memperkuat kesehatan paruparu dan jantung, memacu jantung sehingga aliran darah ke seluruh tubuh lebih baik, khususnya aliran darah dari pembuluh darah balik (vena) di kaki. Selain itu, jalan kaki juga dapat meningkatkan stamina, memperkuat otot-otot, terutama otot tungkai dan menghilangkan stres. Jalan di waktu pagi hari sangat dianjurkan untuk ibu hamil untuk mendapatkan ketenangan dan kesegaran serta memberikan manfaat menghirup udara bersih di pagi hari, menguatkan otot dasar panggul, dapat mempercepat penurunan kepala bayi ke dalam posisi normal dan mempersiapkan mental menghadapi persalinan (Mukhamad Taufik, Nur Chakim, 2014).

Sebagian besar responden mengatakan jalan kaki merupakan hal yang biasa di lakukan di rumahnya karena daerah Argalingga terletak di daerah pegunungan dengan udara yang sejuk, mata pencaharian masyarakatnya adalah berkebun sehingga pada saat dilakukan kegiatan ini tidak mendapatkan kesulitan yang berarti. Berdasarkan fakta di atas peserta yang melakukan jalan kaki 3 kali dalam seminggu memberikan efek yang baik seperti badan menjadi segar, tensi stabil ada yang juga menurun dan ibu akan melakukan rutin agar persalinan lancar tidak ada penyulit apapun. Hal ini diperkuat oleh penelitian sebelumnya bahwa jalan kaki 10 menit dapat membantu menurunkan tekanan darah (Mukhamad Taufik, Nur Chakim, 2014).

Berbagai manfaat jalan kaki menurut Kuntaraf dan Kathleen L.K dalam Kusmiyati (2014) yaitu: 1) berolahraga dengan jalan kaki dapat membuat otot-otot jantung lebih kuat sehingga dapat memompa darah kembali menuju jantung, 2) menormalkan tekanan darah, saat terjadi tekanan darah tinggi dengan berolahraga jalan kaki tekanan darah akan turun, dan sebaliknya jika tekanan darah sedang rendah maka olahraga akan menaikannya, 3) pencegah thrombosis koroner. Penelitian ilmiah menunjukan bahwa berolahraga dapat membuka pembuluh darah sehingga melancarkan laju darah, 4) pencegahan gangguan pencernaaan, dengan jalan kaki tubuh akan membantu usus untuk menggerakkan sisa makanan bersama-sama hingga menambah kegiatan buang air besar. Berjalan kaki selama 10 hingga 15 menit, ditambah pola hidup sehat yang lainnya seperti minum air putih dan makan buah-buahan akan membuat pencernaan menjadi lancar (Kusmiyati, 2014).

Berdasarkan uraian di atas dapat disimpulkan bahwa jalan kaki mempunyai manfaat yang baik bagi tubuh maka sangat direkomendasikan agar ibu hamil rutin melakukan kegiatan ini minimal 3 kali dalam seminggu untuk menghindari hipertensi dalam kehamilan, menjaga 
pola hidup sehat dan harus kontrol secara rutin ke petugas kesehatan agar ibu dan janin sehat.

\section{SIMPULAN}

Setelah dilakukan kegiatan terapi jalan kaki mengalami penurunan tekanan darah pada ibu hamil. Kegiatan ini diharapkan dilakukan rutin agar ibu hamil terjaga kesehatannya dan terhindar dari penyulit kehamilan seperti pre eklampsia.

\section{UCAPAN TERIMA KASIH}

Penulis mengucapkan terimakasih kepada STIKes YPIB Majalengka yang telah memberikan kesempatan untuk melaksanakan salah satu Tri Dharma Perguruan Tinggi yakni Pengabdian Kepada Masyarakat, kepada Puskesmas Argapura atas kesediaannya sebagai tempat pengabdian, kepada Ade Rita dan ibu hamil yang telah berpartisipasi dalam kegiatan ini.

\section{DAFTAR PUSTAKA}

Cunningham F, Leveno K, Bloom S, et. a. (2010). Pregnancy Hypertension. William Obstetrics (24th ed.). New York: McGraw Hill.

Cunningham F, Leveno K, B. et. al. (2003). Gestational Hypertension and Preeclampsia Williams Manual of Pregnancy Complications (23rd ed.). New York.

Dinas Kesehatan Kabupaten Majalengka. (2019). Data Ibu Hamil Hipertensi di Kabupaten Majalengka Tahun 2018. Majalengka.

Dinas Kesehatan Propinsi Jawa Barat. (2018). Derajat Kesehatan Propinsi Jawa Barat Tahun 2017. Bandung: Dinas Kesehatan Propinsi Jawa Barat.

IBG Manuaba. (2015). Ilmu Kebidanan Penyakit Kandunagn dan KB. Jakarta: EGC.
Kemenkes RI. (2018). Profil Kesehatan Indonesia Tahun 2017. Jakarta: Kemenkes RI.

Kusmana. (2016). Olah Raga Untuk Orang Sehat dan Penderita Penyakit Jantung: Trias Sok dan Jalan Kaki 10 Menit. Jakarta: Balai Penerbit FKUI.

Kusmiyati. (2014). Perawatan Ibu Hamil. Yogyakarta: Fitramaya.

Lauralee Sherwood. (2010). Human Physiology From Cells to System (7th ed.). USA.

Mukhamad Taufik, Nur Chakim, N. N. F. (2014). Tekanan Darah Pada Ibu Hamil Primigravida Sebelum dan Sesudah Melakukan Olah Raga Jalan Kaki Selama 10 Menit. Jurnal Ilmiah Kesehatan, 6(1). Retrieved from journal.stikesmuh-pkj.ac.id

Olea MA, et. a. (2017). Effect of High Intensity Interval Training on Blood Pressure in Hypertensive Subjects. Revista Medica JOurnal, 145(9). Retrieved from ncbi.nml.nih.gov

Sabar Surbakti. (2014). Pengaruh Jalan Kaki 30 Menit terhadap Penurunan Tekanan Darah pada Pasien Hipertensi di Rumah Sakit Umum Kabanjahe. Jurnal Pengabdian Kepada Masyarakat, 20(77). Retrieved from jurnal.unimed.ac.id

Yuliarti. (2015). Lengkap Olah Raga Bagi Wanita Hamil dan Menyusui. Yogyakarta: Andi Offset. 